\title{
Relationship of epilithic diatom communities to environmental variables in Homa lagoon (Izmir, Turkey)
}

\author{
Fatma Çolak Sabanci* \\ Ege University, Faculty of Fisheries, Department of Hydrobiology, Bornova 35100, Izmir, Turkey
}

\begin{abstract}
Spatio-temporal changes in taxonomic composition and structure of a diatom community were assessed between June 2006 and June 2007 at the intertidal zone of Homa lagoon, Izmir, Turkey. The communities were composed of a mixture of epilithic, epiphytic, epipsammic, and occasionally some pelagic diatoms. In total, 87 taxa belonging to 39 genera were identified, of which 39 were used as active taxa in the numerical analysis. The Shannon-Wiener diversity index $\left(H^{\prime}\right)$ values were quite variable, varying between 1.00 and 3.39 and correlated with both species richness $(\mathrm{r}=0.93)$ and evenness $\left(J^{\prime} ; \mathrm{r}=0.38\right)$. Cylindrotheca closterium, Halamphora veneta, Licmophora gracilis, L. lyngbyei, Navicula cryptocephala, N. cincta, and N. ramosissima var. mollis were the overall most abundant taxa throughout the sampling. The relationship between epilithic algal communities and 10 environmental variables was explored using canonical correspondence analysis. According to a Monte Carlo unrestricted permutation test, the silicate and ammonium concentrations were the most important variables in accounting for species distribution.
\end{abstract}

KEY WORDS: Benthic diatom - Epilithic - Species diversity · Canonical correspondence analysis · Wetland area $\cdot$ Homa lagoon $\cdot$ Turkey

Resale or republication not permitted without written consent of the publisher

\section{INTRODUCTION}

Coastal lagoons are areas of close contact between a river and the open sea, mixing freshwater from continental drainages and seawater with high levels of salinity. These systems are often characterized by extended intertidal mud- and sand-flats (Lankford 1977). Despite the fact that intertidal benthic biota have to survive in a harsh and variable environment, intertidal flats are sites of intense biological activity, often with high productivity (Herman et al. 1999), supporting large populations of birds and forming feeding areas for coastal fisheries.

Epilithic diatoms are recognized worldwide as one of the most appropriate biological components for water quality assessment, due to their continuous presence along the aquatic system and their quick response to the environmental changes (Salomoni 2004).
Benthic diatoms are present on almost all stable substrata. The benthic assemblage most commonly sampled is epilithon (Wunsam et al. 2002). The advantages and disadvantages of using natural or artificial substrates for sampling have been discussed at length (Watanabe 1990). Artificial substrates are generally selective and inert and do not show the whole natural community. On the other hand, natural substrates present advantages because the stones supply nutrients that support community development. In addition to the advantages and disadvantages of using natural or artificial substrates in lagoonal system, there is also no consensus on the main factors that determine diatom species composition and distribution; therefore, the results from different studies may prove contradictory (Sullivan \& Currin 2000).

Studies conducted in Homa lagoon, Izmir, Turkey, have been focussed on fisheries (Hossucu \& $\mathrm{Ak}$ 
2000), bivalve culture (Serdar \& Lok 2007), and the physical and chemical properties of the lagoon (Unsal et al. 2000), but there is a gap in knowledge concerning epilithic diatoms. Few algological surveys have been conducted in the study area (Çolak Sabanci \& Koray 2010, Çolak Sabanci et al. 2011). Epilithic diatom samples obtained in the present study have a wide spectrum of ecologically different types, including marine, brackish, and even freshwater affinities. In addition to this, samples also contained a mixture of forms growing on the stones themselves, on silt accumulated on the stones, and epiphytic forms on other algae, but here I will refer to this collective community as the epilithon. The aims of the present study were to describe the species composition of diatom assemblages, to determine which environmental factors explain the composition of epilithic diatoms and to assess the response of common diatom taxa to these environmental variables.

\section{MATERIALS AND METHODS}

\section{Study area}

Homa Lagoon $\left(38^{\circ} 33^{\prime} 10^{\prime \prime} \mathrm{N}, 26^{\circ} 49^{\prime} 50^{\prime \prime} \mathrm{E}\right)$ is located $25 \mathrm{~km}$ to the northwest of the Gulf of Izmir and within the borders of the town of Menemen (Fig. 1). The lagoon is $7.4 \mathrm{~km}$ long and $3 \mathrm{~km}$ wide. The Gediz Delta region (20400 ha), which includes the study area, consists of freshwater and salt water marshes
(5000 ha), bays and saltpans (3300 ha), and lagoonal areas (Homa, 1800 ha; Cilazmak, 725 ha; Tas, 500 ha; Kirdeniz, 450 ha) which makes it a typical Mediterranean delta ecosystem. The average rainfall and temperature of the area are $544.2 \mathrm{~mm}$ and $16.8^{\circ} \mathrm{C}$ (Ministry of Environment \& Forestry 2007). Homa lagoon is one of the most important lagoons on the Aegean coast of Turkey, being a biodiversity hotspot. Because of its enormous species diversity and natural habitats, the lagoon was included in the important wetlands list in the Ramsar Convention. It is also the last active lagoon in Izmir Bay. Between June and December, the fish traps are closed and the seawater input is reduced

From June 2006 until June 2007, epilithon samples were collected from 4 stations in Homa lagoon on a monthly basis. Stn 1 was in the sea region and open to the waves. It was deeper than the other stations, and throughout the sampling period the water depth was approximately $1 \mathrm{~m}$. The bottom was extensively covered with broken sea shells. Stns 2 and 3 were located in regions where seawater and lagoon water mix and both had a bottom covered with muddy sediment. Stn 3 was less affected by seawater than Stn 2 . The water depth of these stations varied between 0.6 and $1 \mathrm{~m}$. Stn 4, the shallowest station, was located in a completely sheltered area. It had a muddier bottom structure than the other stations, and the water depth was $<0.5 \mathrm{~m}$. Stn 4 is strongly influenced by meteorological conditions, and, especially in the summer period, drying and fracturing are evident as an effect of evaporation.

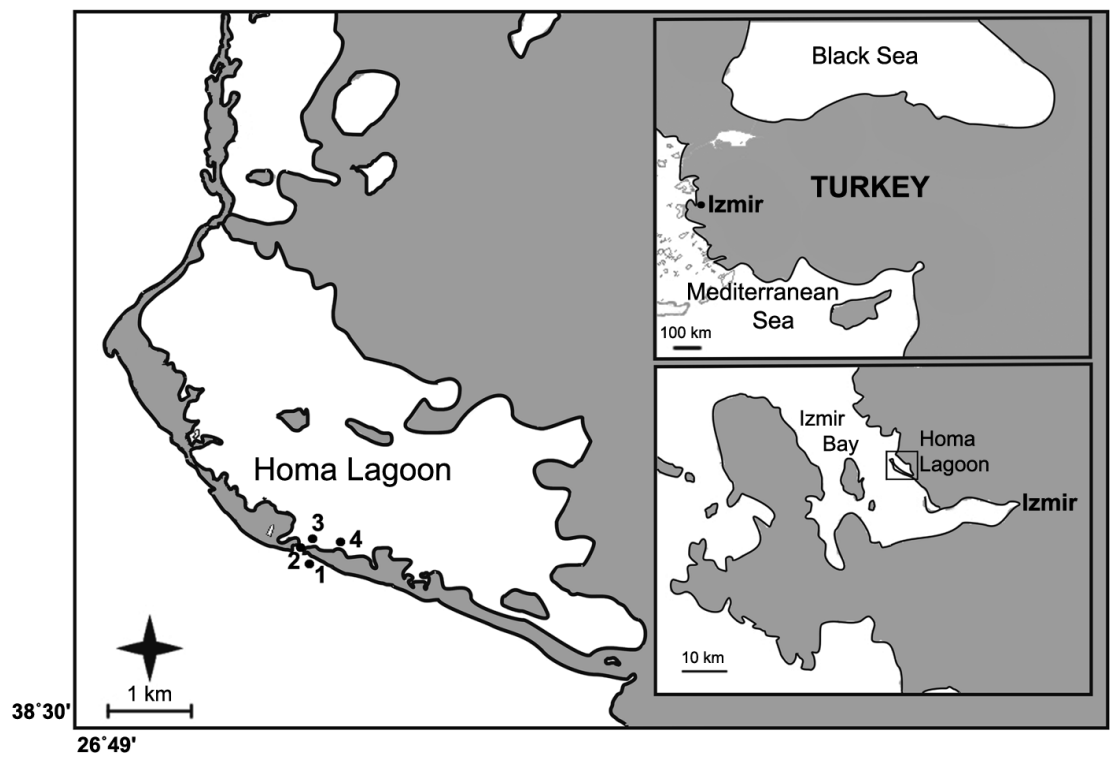

Fig. 1. Location of stations in the Homa Lagoon

\section{Water sampling}

Water samples were taken monthly from the same stations in order to determine the physico-chemical structure of Homa lagoon. Water temperature $\left({ }^{\circ} \mathrm{C}\right)$ and $\mathrm{pH}$ were measured in situ with a mercury thermometer and a HANNA HI 8314 model pH meter. Water samples for analyzing salinity $(\%)$, nitrite $\left(\mathrm{NO}_{2}-\mathrm{N}\right)$, nitrate $\left(\mathrm{NO}_{3}-\mathrm{N}\right)$, ammonium $\left(\mathrm{NH}_{4}-\mathrm{N}\right)$, phosphate $\left(\mathrm{PO}_{4}-\right.$ $\mathrm{P})$, and silicate (Si) were collected in 11 plastic bottles and immediately transferred to the laboratory. Salinity and dissolved oxygen concentration were analyzed according to the methods of Martin (1972) and Winkler (1888), respectively. Chlorophyll a 
(chl a) and nutrient concentrations were determined colorimetrically with an HACH DR/4000 U model spectrophotometer. The method of Strickland \& Parsons (1972) was followed for the colorimetric analysis.

\section{Diatom analysis}

Sampling of epilithic diatoms were performed monthly at the 4 stations. To define the species composition of epilithic diatoms, stones 15 to $20 \mathrm{~cm}$ in diameter were collected (one stone per station per month, for $13 \mathrm{mo}$, yielding 52 samples). Each stone was chosen as randomly as possible amongst those that were not covered with filamentous algae and with an evident film of diatoms. The entire surface area of each stone was scraped clean with a toothbrush in $150 \mathrm{ml}$ of distilled water and preserved with formaldehyde $(4 \%)$. Before counting, the preserved sample was brought to a final volume of $200 \mathrm{ml}$ with distilled water and homogenized at low speed until the sediment was throughly mixed (Winter \& Duthie 2000). The results were expressed as the number of diatom cells $\mathrm{cm}^{-2}$. Three water-mounted slides for each sample were counted at 400× magnification (Utermöhl 1958). Permanent slides for the identification of diatoms from the same sample were prepared chemically with $10 \% \mathrm{HCl}, 30 \% \mathrm{H}_{2} \mathrm{SO}_{4}, \mathrm{KMnO}_{4}$, and oxalic acid (Lauriol et al. 2006). Diatoms were identified to the species level at $1000 \times$ magnification by phase-contrast optics with an OLYMPUS $\times 100$ PlanApo oil-immersion objective following standard diatom preperation methods (Battarbee 1986). Identifications were made following Peragallo \& Peragallo (1897-1908), Hendey (1964), Hartley (1996), and Witkowski et al. (2000).

\section{Data analyses}

The Shannon-Wiener index $\left(H^{\prime} ; \log\right.$ base $\left.=\mathrm{e}\right)$ and Pielou's evenness index $\left(J^{\prime}\right)$ were calculated from relative abundance values (RA, \%). Differences in $H^{\prime}$ values were tested using a non-parametric KruskalWallis ANOVA median test. Diatom counts of all 52 samples were first converted into RA. The RA values were used in the multivariate analysis and were the means of 3 replicate samples. Only the taxa which had an RA of at least $1 \%$ in any single sample were taken into consideration. In total, 87 taxonomic entities were distinguished, of which 39 were used as active taxa in the numerical analysis.
All environmental variables were tested for skewness. The environmental variables, with the exception of nitrate, phosphate, salinity, $\mathrm{Si} / \mathrm{N}$ ratio, and $\mathrm{Si} / \mathrm{P}$ ratio, had a skewed distribution and were log $(x+1)$ transformed.

Canonical correspondence analysis (CCA) was used to identify statistically significant directions of variations within the 52 samples. CCA is a powerful, statistically robust procedure for analyzing complex biological data (e.g. diatom percantages) and their relation to environmental variables (e.g. salinity, temperature). It provides a simultaneous low-dimensional representation of diatom taxa, samples, and environmental variables (Birks et al. 1990). A code was assigned to the species used in the CCA analyses (see Table 2). Species abundance data were log $(x+1)$ transformed prior to the analysis. Pearson's correlation analysis was used to assess the relationships between environmental variables and community parameters. All statistical analyses were conducted using the PRIMER package (Clarke \& Warwick 2001), Statistica 7.0, Statgraphics Plus 5.1, and the CANOCO 4.5 package (ter Braak \& Šmilauer 2002). Significance was accepted at $\mathrm{p} \leq 0.05$ for all statistical tests used in this study.

\section{RESULTS}

\section{Physical and chemical characteristics}

During the sampling period, surface water temperature of the lagoon varied between 4 and $29^{\circ} \mathrm{C}$, with the maximum temperature recorded in August 2006 at Stn 4, and the minimum in December 2006 at Stns 1 and 2. The salinity ranged between 29.12 in October 2006 at Stn 1 and 54.12 in December 2006 at Stn 4. Dissolved oxygen concentrations were measured with a minimum of $4.80 \mathrm{mg} \mathrm{l}^{-1}$ in January 2007 at Stn 2 and a maximum of $28.00 \mathrm{mg}$ $1^{-1}$ in December 2006 at Stn 4. Significant freshwater input into the study area was provided by rainfall. During autumn, the observed rainfall was less than expected, and the fish traps were closed between June and December; therefore, the seawater input was weak in this period. For these reasons, high salinity values were observed in the sheltered region (Stn 4). Also in December 2006, a high oxygen value was determined at the same station. This may have been due to water mixing caused by wind. The $\mathrm{pH}$ was mostly stable throughout the sampling period, and the highest value (8.48) was detected in April 2007 at Stn 2. 
Table 1. Correlation matrix for the 13 environmental variables measured in the study. DO: dissolved oxygen, $\mathrm{NO}_{3}-\mathrm{N}$ : nitrate, $\mathrm{NO}_{2}-\mathrm{N}$ : nitrite, $\mathrm{NH}_{4}-\mathrm{N}$ : ammonium, $\mathrm{PO}_{4}-\mathrm{P}$ : phosphate, Si: silicate, N/P: N/P ratio, Si/N: Si/N ratio, Si/P: Si/P ratio, Chl a: chlorophyll a. ${ }^{*} \mathrm{p} \leq 0.05$

\begin{tabular}{|c|c|c|c|c|c|c|c|c|c|c|c|c|c|}
\hline & Temperature & Salinity & $\mathrm{pH}$ & DO & $\mathrm{NO}_{3}-\mathrm{N}$ & $\mathrm{NO}_{2}-\mathrm{N}$ & $\mathrm{NH}_{4}-\mathrm{N}$ & $\mathrm{PO}_{4}-\mathrm{P}$ & $\mathrm{Si}$ & N/P & $\mathrm{Si} / \mathrm{N}$ & $\mathrm{Si} / \mathrm{P}$ & Chl a \\
\hline Temperature & 1.00 & & & & & & & & & & & & \\
\hline Salinity & $-0.33^{*}$ & 1.00 & & & & & & & & & & & \\
\hline $\mathrm{pH}$ & 0.14 & 0.13 & 1.00 & & & & & & & & & & \\
\hline DO & -0.22 & 0.17 & 0.15 & 1.00 & & & & & & & & & \\
\hline $\mathrm{NO}_{3}-\mathrm{N}$ & -0.15 & 0.10 & -0.10 & 0.20 & 1.00 & & & & & & & & \\
\hline $\mathrm{NO}_{2}-\mathrm{N}$ & $-0.38^{*}$ & 0.06 & -0.14 & -0.14 & 0.14 & 1.00 & & & & & & & \\
\hline $\mathrm{NH}_{4}-\mathrm{N}$ & $0.57^{*}$ & $-0.33^{*}$ & 0.11 & $-0.43^{*}$ & $-0.28^{*}$ & $-0.35^{*}$ & 1.00 & & & & & & \\
\hline $\mathrm{PO}_{4}-\mathrm{P}$ & -0.15 & 0.06 & -0.18 & 0.06 & -0.05 & $0.65^{*}$ & $-0.42^{*}$ & 1.00 & & & & & \\
\hline $\mathrm{Si}$ & -0.04 & -0.17 & $-0.30^{*}$ & 0.21 & 0.03 & 0.19 & -0.20 & $0.41^{*}$ & 1.00 & & & & \\
\hline N/P & -0.01 & -0.22 & 0.07 & 0.00 & $0.63^{*}$ & -0.17 & 0.26 & $-0.61^{*}$ & -0.19 & 1.00 & & & \\
\hline $\mathrm{Si} / \mathrm{N}$ & -0.14 & -0.12 & -0.25 & 0.18 & $-0.41^{*}$ & 0.21 & $-0.27^{*}$ & $0.51^{*}$ & $0.77^{*}$ & $-0.54^{*}$ & 1.00 & & \\
\hline $\mathrm{Si} / \mathrm{P}$ & 0.01 & $-0.31^{*}$ & 0.11 & 0.12 & 0.01 & $-0.36^{*}$ & 0.21 & $-0.55^{*}$ & 0.27 & $0.54^{*}$ & 0.01 & 1.00 & \\
\hline Chl a & 0.17 & -0.04 & 0.05 & -0.08 & -0.03 & $-0.29^{*}$ & $0.30^{*}$ & -0.19 & -0.25 & 0.06 & -0.26 & -0.06 & 1.00 \\
\hline
\end{tabular}

During the sampling period, the maximum amounts of nitrite, nitrate, and ammonium were $1.13 \mu \mathrm{M}$ (March 2007, Stn 1), $34.57 \mu \mathrm{M}$ (November 2006, Stn 4), and 7.20 $\mu \mathrm{M}$ (June 2006, Stn 1, respectively. Phosphate amounts ranged between $0.15 \mu \mathrm{M}$ in October 2006 at Stn 4 and $2.60 \mu \mathrm{M}$ in March 2007 at Stn 1. Silicate amounts ranged between $1.64 \mu \mathrm{M}$ in November 2006 at Stn 1 and $12.90 \mu \mathrm{M}$ in March 2007 at Stn 4. The lowest N/P ratio occurred in March 2007 at Stn 1 (2.51), while the highest value was recorded in November 2006 at Stn 4 (76.17). The maximum $\mathrm{Si} / \mathrm{P}$ ratio was determined in October 2006 at Stn 4 (37.67) and the minimum in April 2007 at Stn 2 (2.10), whereas the maximum $\mathrm{Si} / \mathrm{N}$ ratio was observed in March 2007 at Stn 4 (2.53) and the minimum in November 2006 at Stns 3 and 4 (0.15). Minimum and maximum lagoon water chl $a$ values were $0.10 \mu \mathrm{g} \mathrm{l}^{-1}$ (December 2006, Stn 4; March 2007, Stns 3 and 4; April 2007, Stn 4) and $17.62 \mu g l^{-1}$ (June 2006, Stn 3). Table 1 shows the results of the correlation analysis $(\mathrm{r}=$ Pearson product-moment correlation) among environmental parameters.

\section{Biological characteristics}

In total, 87 taxa belonging to 39 genera were determined from 4 stations in the Homa lagoon. The maximum num-
Table 2. Species found in Homa lagoon and the abbreviation codes used in the canonical correspondence analyses

\begin{tabular}{|c|c|}
\hline Species & Code \\
\hline Achnanthes brevipes C. Agardh & ACH BREV \\
\hline Cocconeis placentula Ehrenberg & COC PLAC \\
\hline Cocconeis scutellum Ehrenberg & COC SCUT \\
\hline $\begin{array}{l}\text { Craticula cuspidata (Kutzing) D.G. Mann in Round, Crawford } \\
\text { \& Mann }\end{array}$ & CRA CUSP \\
\hline Ctenophora pulchella (Ralfs ex Kützing) D.M. Williams \& Round & CTE PULC \\
\hline Cylindrotheca closterium (Ehrenberg) Reimann \& J.C. Lewin & CYL CLOS \\
\hline Eunotogramma marinum (W.Smith) H. Peragallo & EUN MARI \\
\hline Grammatophora oceanica Ehrenberg & GRA OCEA \\
\hline Gyrosigma spencerii (J.W. Bailey ex Quekett) Griffith \& Henfrey & GYR SPEN \\
\hline Halamphora turgida (Gregory) Levkov & HAL TURG \\
\hline Halamphora veneta (Kützing) Levkov & HAL VENE \\
\hline Licmophora gracilis (Ehrenberg) Grunow & LIC GRAC \\
\hline Licmophora lyngbyei (Kützing) Grunow ex Van Heurck & LIC LYNG \\
\hline Mastogloia braunii Grunow & MAS BRAU \\
\hline Mastogloia pumila Cleve & MAS PUMI \\
\hline Navicula cincta (Ehrenberg) Ralfs in Pritichard & NAV CINC \\
\hline Navicula cryptocephala & NAV CRYP \\
\hline Navicula distans & NAV DIST \\
\hline Navicula forcipata var. densestriata A.W.F.Schmidt & NAV FODE \\
\hline Navicula menaiana Hendey & NAV MENA \\
\hline Navicula menisculus Schumann & NAV MENI \\
\hline Navicula radiosa Kützing & NAV RADI \\
\hline Navicula ramosissima var. mollis (W. Smith) Hendey & NAV RAMO \\
\hline Navicula trivialis Lange-Bertalot & NAV TRIV \\
\hline Nitzschia debilis (Arnott) Grunow in Cleve \& Grunow & NIT DEBI \\
\hline Nitzschia dissipata (Kützing) Grunow & NIT DISS \\
\hline Nitzschia frustulum (Kützing) Grunow in Cleve \& Grunow & NIT FRUS \\
\hline Nitzschia longissima (Brébisson) Ralfs in Pritchard & NIT LONG \\
\hline Nitzschia sigma (Kützing) W. Smith & NIT SIGM \\
\hline Pinnularia viridis (Nitzsch) Ehrenberg & PIN VIRI \\
\hline Pleurosigma salinarum (Grunow) Grunow in Cleve \& Grunow & PLE SALI \\
\hline Psammodictyon panduriforme (W. Gregory) D.G. Mann in & \\
\hline Round, Crawford \& Mann & PSA PAND \\
\hline Rhabdonema adriaticum Kützing & RHA ADRI \\
\hline Seminavis robusta D.B. Danielidis \& D.G.Mann & SEM ROBU \\
\hline Striatella unipunctata (Lyngbye) C. Agardh & STR UNIP \\
\hline Synedra gaillonii (Bory de Saint-Vincent) Ehrenberg & SYN GAIL \\
\hline Tabularia fasciculata (C. Agardh) D.M. Williams \& Round & TAB FASC \\
\hline Toxonidea insignis Donkin & TOX INSI \\
\hline Tryblionella acuminata W. Smith & TRY ACUM \\
\hline
\end{tabular}





Fig. 2. Monthly variations in relative abundance of the 7 most abundant taxa (mean $\pm \mathrm{SD}$ )

ber of species with 67 taxa was found at Stn 2, of which 41 taxa were also observed at Stn 4, which had a slightly lower number of species (50). In terms of total epilithic diatom density, considerable differences were recorded among the stations. The highest total numbers were recorded in April 2007 (75693 cells $\mathrm{cm}^{-2}$ ) at Stn 3 and in September 2006 (120086

cells $\mathrm{cm}^{-2}$ ) at Stn 3 due to a sharp increase in cell numbers of Navicula cryptocephala.

The most abundant diatom taxa encountered are listed in Table 2. The percentage of species with a maximum RA (the highest RA value observed during the study period) of $54 \%$ in a sample was less than $5 \%$, with approximately $28 \%$ of species having an 
RA of less than $10 \%$. Only 7 taxa occurred at a maximum RA of over $10 \%$ (Fig. 2), and some of these were either planktonic or belonged to the genus Navicula. These 7 were also generally frequent within the data. Cylindrotheca closterium (maximum RA $20 \%$ ) and $N$. cryptocephala (maximum RA $24 \%$ ) were the overall most abundant taxa throughout the sampling. There were some other species such as Halamphora veneta, Licmophora gracilis, L. lyngbyei, N. cincta, and N. ramosissima var. mollis which occurred in all samples, showing maximum RA values of more than $10 \%$ during some periods. Although the abundant taxa were registered in all samples, they exhibited some differences in their spatial distribution in relation to sampling period. The RA of $H$. veneta was substantially higher $(>10 \%)$ in September 2006 (Stns 2 and 3), L. gracilis in July 2006 (Stn 3), L. lyngbyei in July 2006 and in April 2007 (Stn 3), and N. cincta in April 2007 (Stns 1 and 3).

The Shannon-Wiener $H^{\prime}$ values were quite variable, varying between 1.00 and 3.39, and correlated with species richness $(\mathrm{r}=0.93)$, which varied from 3 to 34 , and evenness $\left(J^{\prime} ; \mathrm{r}=0.38\right)$, which ranged from 0.66 to 0.98 . Median diversity was lower for Stn 4 (2.12) than for Stn 2 (3.06), Stn 3 (2.76), and Stn 1 (2.26; Fig. 3). Differences in $H^{\prime}$ values among sampling sites were statistically significant.

\section{Ordination and classification}

The relationships between the diatom assemblages and the environmental variables were explored in more detail using CCA and the results are plotted in

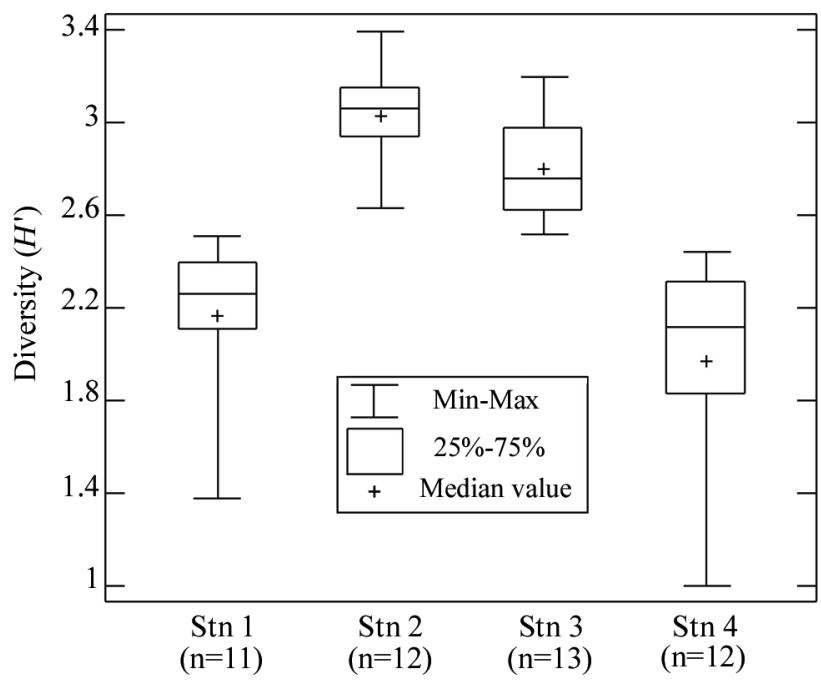

Fig. 3. Differences in the values of the Shannon-Wiener diversity index $\left(H^{\prime}\right)$ at the 4 sampling sites

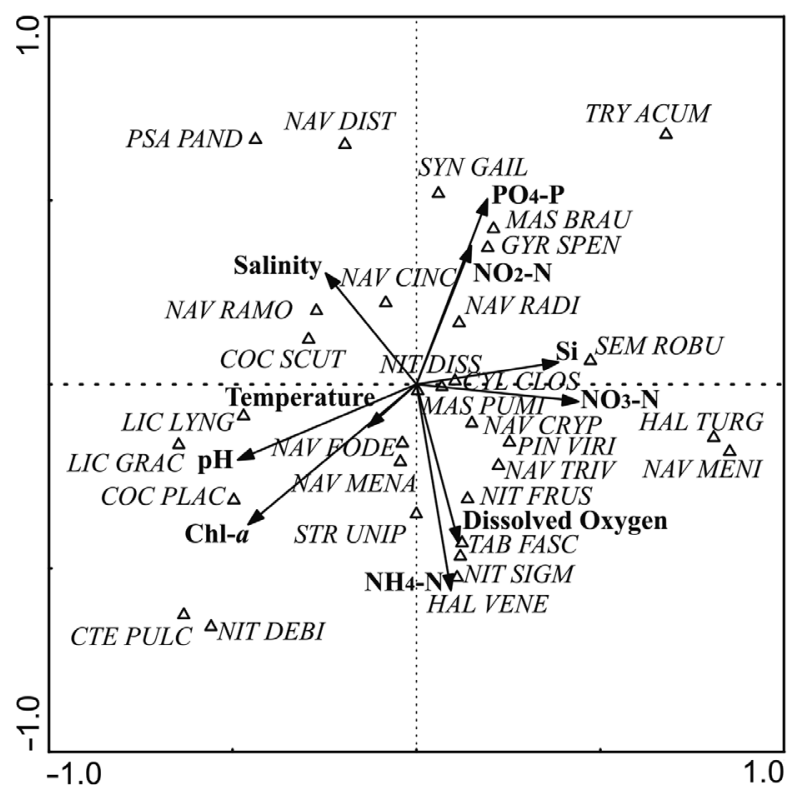

Fig. 4. Canonical correspondence analysis of 52 samples from 4 sites. For abbrevations see Tables 1 \& 2

Fig. 4. The result of the CCA ordination for 39 diatom species, 10 environmental variables, and 52 samples showed that $24 \%$ of the variance in species abundance was accounted for by the first 4 ordination axes. The eigenvalues for CCA axes 1 and 2 are 0.48 and 0.33 , and the species-environment correlations for CCA axes 1 (0.87) and 2 (0.85) are high. After evaluating the importance of all 10 environmental variables by forward selection of the environmental variables, Monte Carlo unrestricted permutation tests of the statistical significance, canonical coefficient and intra-set correlations between environmental variables and the axes, the $\mathrm{Si}$ and $\mathrm{NH}_{4}-\mathrm{N}$ concentrations were the most important environmental variables accounting for species distribution. The distribution of species along the first axis reflects their requirements with regard to $\mathrm{Si}$ and $\mathrm{NH}_{4}-\mathrm{N}$ in which the 2 environmental variables capture about $41 \%$ of the total variance and $\mathrm{Si}$ concentration alone accounts for about $24 \%$. The distributions of Halamphora veneta, $H$. turgida, Mastogloia pumila, Navicula cryptocephala, N. menisculus, $N$. trivialis, Nitzschia frustulum, Nitzschia sigma, Pinnularia viridis, and Tabularia fasciculata are positively correlated to $\mathrm{NO}_{3}-\mathrm{N}$ and $\mathrm{NH}_{4}-\mathrm{N}$ and negatively correlated to salinity. Gyrosigma spencerii, M. braunii, Navicula radiosa, and Synedra gaillonii are positively correlated to $\mathrm{NO}_{2}-\mathrm{N}$ and $\mathrm{PO}_{4}-\mathrm{P} ;$ Cylindrotheca closterium, Navicula dissipata, and Seminavis robusta are positively correlated to Si concentrations and negatively correlated to $\mathrm{pH}$ and temperature; and Cocconeis 
scutellum, Navicula cincta, and N. ramosissima var. mollis are positively correlated to salinity and negatively correlated to nutrient concentrations. Also, $C$. placentula, N. forcipata var. densestriata, N. menaiana, Licmophora gracilis, and L. lyngbyei are strongly positively correlated to $\mathrm{pH}$ and temperature (Fig. 4).

\section{DISCUSSION AND CONCLUSIONS}

The present investigation showed that the epilithic assemblage of the Homa lagoon appeared to be relatively homogeneous, and few species made a significant contribution to the assemblage structure. Cylindrotheca closterium, C. placentula, Halamphora veneta, Licmophora gracilis, L. lyngbyei, Navicula cincta, N. cryptocephala, N. distans, N. ramosissima var. mollis, $N$. trivialis, and Pinnularia viridis were the dominant species, and the monthly succession of these species constituted the most important portion of assemblage structure. In this study, some diatom species sometimes strongly predominated over the others in the composition of the epilithic community (RA of C. closterium at Stn 1 was $41 \%$ in August 2006 and $52 \%$ in December 2006; RA of N. cryptocephala at Stn 4 was $49 \%$ in September 2006, 30\% in October 2006, and $53 \%$ in November 2006).

Several studies have investigated the spatial distribution of epilithic diatoms and revealed correlations between the species distribution and salinity, temperature, amount of sand grains, and macroalgae on the stones (Ulanova \& Snoeijs 2006). These studies have compared several sites from different mudflats (Underwood 1994), or sampled along salinity (Ulanova \& Snoeijs 2006) or pollution gradients (Admiraal \& Peletier 1980), or with water movement (Delgado et al. 1991) or the microalgal biomass (Kendrick et al. 1996). The area in the present study is characterized by a highly dynamic environment, basically because of the frequent changes of physical characteristics due to shallowness. Depending on the depths of the stations, they are exposed to varying degrees of wind and wave action, which has an important effect in the regional composition of diatom species. Water turbulance can lead to biomass losses of up to $80 \%$ (Hoagland 1983), and, at wave-exposed sites, the high water column primary productivity can be largely $(90 \%)$ caused by resuspension of the benthic diatom flora (Shaffer \& Sullivan 1988). In very shallow waters, benthic and planktonic communities are not clearly differentiated, mainly due to the continuous mixture of the shallow water column. Therefore, it is not unusual to find a typical planktonic species such as Cylindrotheca closterium as the dominant species in a sessile community.

Ordination techniques have been used successfully to interpret epilithic diatom community structure. In this study, it was possible to describe the relationships of species-environmental factors. As a result of CCA analyses, the distribution of community composition was clearly correlated, particularly with variations in $\mathrm{Si}$ and $\mathrm{NH}_{4}-\mathrm{N}$. Non-restrictive silicate conditions are favorable for diatoms, which are excellent competitors at high $\mathrm{Si} / \mathrm{N}$ ratios (N-limitation) and high Si/P ratios (P-limitation; Sommer 1996). High concentrations of silica can promote diatom growth and strong silicification of diatom frustules (Busse \& Snoeijs 2003). The mean ratios of $\mathrm{Si} / \mathrm{N}$ (range: $0.15-2.53$ ) and $\mathrm{Si} / \mathrm{P}$ (range: $2.10-37.67$ ) in the study area were 0.66 and 10.4 , respectively. The values $\mathrm{Si} / \mathrm{N}$ (except March 2007) and Si/P were below the Redfield ratio during the sampling, which indicates that silicate was likely the limiting factor for the growth of diatoms in the Homa lagoon. Under $\mathrm{N}$ limitation, diatoms are capable of relatively high $\mathrm{Si}$ uptake, which ultimately results in smaller and tougher frustules (Lynn et al. 2000). Variations in salinity, usually a significant structuring factor (Weckström \& Juggins 2005), had no effect on the composition of the diatom communities of the Homa lagoon. This is an expected situation, given a lack of marked changes in the salinty values. Adaptation to changes in salinity is a prerequisite for diatoms living in these environments.

Diatoms in the center of the CCA ordination diagram are rather complex, including both marine planktonic and benthic species, and even a few brackish water species. The analyses indicated that some species in the Homa lagoon respond positively to increased nutrient concentrations: Halamphora veneta, Nitzschia frustulum, and Tabularia fasciculata to $\mathrm{NH}_{4}-\mathrm{N}_{\text {; }}$ and Gyrosigma spencerii, Mastogloia braunii, Navicula radiosa, and Synedra gaillonii to $\mathrm{NO}_{2}-\mathrm{N}$ and $\mathrm{PO}_{4}$-P. In a marine study by Busse \& Snoeijs (2003), T. fasciculata were favored by Si and $\mathrm{Si} / \mathrm{N}$, and $N$. frustulum responded negatively to $\mathrm{P}$ and positively to $\mathrm{Si} / \mathrm{P}$ and N/P. N. frustulum can be found at extremely high abundances in strongly eutrophied waters with heavy sewage impact (Wendker 1990). Cocconeis placentula, C. scutellum, and Ctenophora pulchella grouped in the direction of higher salinity and were defined as typical epiphytes (Ulanova \& Snoeijs 2006). There is some controversy about the ecology of C. placentula. Pipp \& Rott (1993) considered that the occurrence and abundance of $C$. placentula can be favored by $\mathrm{NO}_{3}$ increases. How- 
ever, the findings of the present study were similar to those of Eulin (1997), and the same species were found not to be affected by the water nutrient content. Craticula cuspidata, G. spencerii, and Navicula trivialis have been reported to have no habitat specificity (Townsend \& Gell 2005). Similarly, in the present study, these species did not appear to be specific to the stubtrata in Homa Lagoon. This is not surprising because in a study carried out on artificial substratum, epilithic species were observed first (Munda 2005). The same study also reported that sand particles accumulated on the study plaques over time, depending on water movements, and, consequently, epipelic and epipsammic species were seen in addition to the epilithic species. Therefore, the species composition of the epilithic community was made up of planktonic, epipelic, and epipsammic algae.

The species defined in lagoonal systems are usually quite mixed and often difficult to interpret, because the distribution of epilithic diatoms is not only controlled by the substratum but also by biotic and abiotic factors. In transitional systems, the continual changes of these factors, and interactions between them, make it difficult to understand which factor(s) is (are) affecting the community structure. Microphytobenthic studies are important for understanding the general ecology of benthic communities. In this context, studies similar to the present study (i.e. analysing benthic diatom community composition in the Homa lagoon) could be helpful in future quantitative evaluations of species composition and their responses to environmental gradients.

Acknowledgements. I am grateful to the Fisheries Faculty, Ege University for providing their facilities. I acknowledge the reviewers of the paper for their constructive comments which have helped improve the quality of this manuscript.

\section{LITERATURE CITED}

Admiraal W, Peletier H (1980) Distribution of diatom species on an estuarine mud flat and experimental analysis of the selective effect of stress. J Exp Mar Biol Ecol 46:157-175

Battarbee RW (1986) Diatom analysis. In: Berglund BE (ed) Handbook of Holocene palaeoecology and palaeohydrology. John Wiley \& Sons, Chichester, p 527-570

Birks HJB, Juggins S, Line JM (1990) Lake surface-water chemistry reconstructions from palaeolimnological data. In: Mason BJ (ed) The surface water acidification programme. Cambridge University Press, Cambridge, p 301-313

Busse S, Snoeijs P (2003) Gradient responses of diatom communities in the Bothnian Sea (northern Baltic Sea), with emphasis on responses to water movement. Phycologia 42:451-464
Clarke KR, Warwick RM (2001) Changes in marine communities: an approach to statistical analysis and interpretation. PRIMER-E, Plymouth

Çolak Sabanci F, Koray T (2010) Four new records for the benthic diatoms (genera Cocconeis, Seminavis, Synedra, and Trachysphenia) from the Aegean Sea. Turk J Bot 34: 531-540

Çolak Sabanci F, Sapanci M, Koray T, Buyukisik B (2011) A qualitative study of the microphytobenthic communities of Homa Lagoon (Izmir-Turkey). Fresenius Environ Bull 20:346-353

Delgado M, De Jonge VN, Peletier H (1991) Experiments on resupension of natural microphytobenthos populations. Mar Biol 108:321-328

Eulin A (1997) Les communautés de diatomées épilithiques de la Garonne. PhD thesis, University Paul Sabatier, Toulouse

Hartley B (1996) An atlas of British diatoms. Biopress Limited, Bristol

Hendey NI (1964) An introductory account of the smaller algae of British coastal waters. Part V: Bacillariophyceae (Diatoms). Fisheries Investigations Series IV. HMSO, London

Herman PMJ, Middelburg JJ, Van de Koppel J, Heip CHR (1999) Ecology of estuarine macrobenthos. Adv Ecol Res 29:195-240

Hoagland KD (1983) Short-term standing crop and diversity of periphytic diatoms in a eutrophic reservoir. J Phycol 19:30-38

Hossucu B, Ak Y (2000) Ichthyoplankton of the Homa Lagoon. Ege Univ J Fish Aquat Sci 17:197-212 (Turkish with English abstract)

Kendrick GA, Jacoby CA, Heinemann D (1996) Benthic microalgae: comparisons of chlorophyll-a in mesocosms and field sites. Hydrobiologia 326-327:283-289

Lankford RR (1977) Coastal lagoons of Mexico: the origin and classification. In: Wiley $M$ (ed) Estuarine processes, Vol 2. Academic Press, New York, NY, p 182-215

Lauriol B, Prévost C, Lacelle D (2006) The distribution of diatom flora in ice caves of the northern Yukon Territory, Canada: relationship to air circulation and freezing. Int $\mathrm{J}$ Speleol 35:83-92

> Lynn SG, Kilham SS, Kreeger DA, Interlandi SJ (2000) Effect of nutrient availability on the biochemical and elemental stoichiometry in the freshwater diatom Stephanodiscus minutulus (Bacillariophyceae). J Phycol 36:510-522

Martin DF (1972) Marine chemistry, Vol 1. Analytical methods. Marcel Dekker Inc., New York, NY

Ministry of Environment \& Forestry (2007) Wetland management plan of Gediz Delta. Ministry of Environment \& Forestry, General Directorate of Nature Protection \& National Parks, Wetlands Division, Izmir

Munda IM (2005) Seasonal fouling by diatoms on artificial substrata at different depths near Piran (Gulf of Trieste, Northern Adriatic). Acta Adriat 46:137-157

Peragallo H, Peragallo M (1897-1908) Diatomées marines de France, et des districts maritimes voisins. MicrographieEditeur, Grez-sur-Loing

Pipp E, Rott E (1993) Bestimmung der ökologischen Wertigkeit von Fliessgewässern in Österreich nach dem Algenaufwuchs. Blaue Reihe des Bundesministeriums für Umwelt, Jugend und Familie 2, Vienna

Salomoni SE (2004) Diatomáceas epilíticas indicadoras da qualidade de água na bacia do Rio Gravataí, Rio Grande do Sul, Brasil. PhD thesis. PPGERN UFSCar, São Carlos, São Paulo 
Serdar S, Lok A (2007) Impact of planting season on growth and survival of the carpet shell clam (Tapes decussatus, Linnaeus 1758). Isr J Aquacult Bamidgeh 59:43-47

Shaffer GP, Sullivan M (1988) Water column productivity attributable to displaced benthic diatoms in well-mixed shallow estuaries. J Phycol 24:132-140

Sommer U (1996) Nutrient competition experiments with periphyton from the Baltic Sea. Mar Ecol Prog Ser 140: 161-167

Strickland JD, Parsons TR (1972) A practical handbook of seawater analysis, 2nd edn. Bulletin 167, Fisheries Research Board of Canada, Ottawa

Sullivan MJ, Currin CA (2000) Community structure and functional dynamics of benthic microalgae in salt marshes. In: Weinstein MP, Kreeger DA (eds) Concepts and controversies in tidal marsh ecology. Kluwer Academic Publishers, Dordrecht

ter Braak CJF, Šmilauer P (2002) CANOCO reference manual and CanoDraw for Windows user's guide: software to canonical community ordination (version 4.5). Ithaca, NY

Townsend SA, Gell PA (2005) The role of substrate type on benthic diatom assemblages in the Daly and Roper Rivers of Australian wet/dry tropics. Hydrobiologia 548: 101-115

Ulanova A, Snoeijs P (2006) Gradient responses of epilithic diatom communities in the Baltic Sea proper. Estuar Coast Shelf Sci 68:661-674

Underwood GJC (1994) Seasonal and spatial variation in epipelic diatom assemblages in the Severn Estuary.

Editorial responsibility: Riccardo Cattaneo-Vietti, Genova, Italy
Diatom Res 9:451-472

Unsal S, Buyukisik B, Akyol O (2000) Discussions on the primary results of the sea parameters in Homa Lagoon (Izmir Bay, Aegean Sea). Ege Univ J Fish Aquat Sci 17:85-94 (Turkish with English abstract)

Utermöhl H (1958) Zur Vervollkommnung der quantitativen Phytoplankton-Methodik. Mitt Int Ver Theor Angew Limnol 9:1-38

Watanabe T (1990) Perifiton: comparação de metodologias empregadas para caracterizar o nível de poluição das águas. Acta Limnol Bras 3:593-615

> Weckström K, Juggins S (2005) Coastal diatom-environment relationships from the Gulf of Finland, Baltic Sea. J Phycol 42:21-35

Wendker S (1990) Morphologische Untersuchungen an Populationen aus dem Formenkreis um Nitzschia frustulum (Klitzing) Grunow. Diatom Res 5:179-187

Winkler LW (1888) The determination of dissolved oxygen in water. Ber Dtsche Chem Ges 21:2843-2855

> Winter JG, Duthie HC (2000) Stream epilithic, epipelic and epiphytic diatoms: habitat fidelity and use in biomonitoring. Aquat Ecol 34:345-353

Witkowski A, Lange-Bertalot H, Metzeltin D (2000) Diatom flora of marine coasts I. In: Lange-Bertalot $\mathrm{H}$ (ed) Iconographia diatomologica, Vol 7. Gantner Verlag ARG, Koeltz Scientific Books, Königstein

> Wunsam S, Cattaneo A, Bourassa N (2002) Comparing diatom species, genera and size in biomonitoring: a case study from the streams in the Laurentians (Quebec, Canada). Freshw Biol 47:325-340

Submitted: May 6, 2011; Accepted: July 25, 2011

Proofs received from author(s): September 23, 2011 